\title{
Hygienic Handling and Processing of Raw Beef Meat at Slaughter Houses and Meat Stalls in Gojjam Area, Ethiopia
}

\author{
Research Article
}

Birhanu $\mathrm{S}^{1,2^{*}}$, Menda $\mathrm{S}^{2,3}$

${ }^{1}$ College of Agricultural Sciences, Department of Animal Sciences, ArbaMinch University, Ethiopia.

${ }^{2}$ Department of Animal Sciences, DebreMarkos University, Ethiopia.

${ }^{3}$ Ministry of Livestock and Fisheries, Ethiopia.

\section{Abstract}

A cross sectional study was conducted to assesses human resource capabilities, sanitation of slaughter houses and processing materials; and hygienic indicator microorganisms and specific foodborne pathogens. Observation survey was undertaken at all slaughter houses and meat-stalls; while interview data were collected from 54 slaughter house butchers. At the same time 21 meat samples were collected from 4, 8, 4 and 5 randomly selected meat stalls of Bure, Debremarkos, Dejen and Fenoteselam respectively from April to August. Slaughter house workers were not professionally trained and certified; most of them were not used aprons, hair cover and gumboots; and all had no overall cloth. The entire abattoirs had no clear division for slaughtering process, which undertaken simply on the ground and hanging were take place on simply constructed wood. Relatively Debremarkos (46.15\%) abattoir had better sanitary standard, and followed with Fenoteselam (23.08\%), Bure (15.38\%) and Dejen $(7.69 \%)$. The mean count of Enterobacteriaceae was not significantly $(P \geq 0.05)$ different; but Escherichia coli, and Salmonella and Shigella species were significantly $(P<0.05)$ different between places. From the total 33 bacterial isolates Escherichia coli $(0.762)$ and Proteus vulgaris (0.381) were found in a higher ratio as compared with Salmonella Species (0.19), Shigellaflexneri (0.143) and Klebsiella pneumonia (0.095). In general the result of this study indicates poor hygienic handling practices of the raw meat production, so this could result in public health risk to the consumers. Hence it needs improved hygienic practice at all levels in the raw meat production industry.

Keywords: Goijam; Slaughter House; Meat Stalls; Meat; Microbial Quality.

\section{Introduction}

Meat consumption in developing countries has been continuously increasing from a modest average annual per capita consumption of $10 \mathrm{~kg}$ in the $1960 \mathrm{~s}$ to $26 \mathrm{~kg}$ in 2000, and will reach $37 \mathrm{~kg}$ around the year 2030 [1]. In order to uphold the meat demand sanitation of abattoirs and providing quality meat has significant value. Cleaning and sanitation are an integral part of slaughtering and handling of meat and should already be taken into consideration at the planning and construction stage of slaughter facilities. Meat production and storage areas need to be constructed with materials that are readily and thoroughly cleanable. In addition butchers should be trained and aware the sanitary precautions.

Meat is potentially subjected to contamination from a range of sources within and outside animal during the slaughter of animal and during its sale. In fact, tissue from healthy animal are sterile however, bacterial pathogens associated with meats can pose risks with food poisoning; and contamination may be associated with the animals themselves, or be introduced to a clean carcass through cross contamination [2]. Contamination during slaughter, dressing and cutting, microorganisms came chiefly from the exterior of the animal mainly from the hide of the animal and the faeces and its intestinal tract but that more added from knives, cloths, air, carts and equipment in general [3]; place of slaughter, the environment of the slaughter house [4]; the floor of the retail outlet, the air in the outlet and the vehicle used for the transport of the meat from the slaughter house to the retail outlet act as the external sources for the contamination of the meat [5]. On the other hand, foodborne diseases are an important cause of morbidity and mortality in worldwide but the full extent and cost of unsafe food [6]. So as to supply healthy food for the consumer's

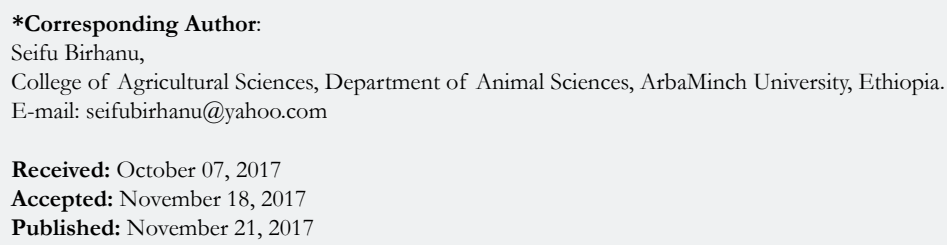

Copyright: Birhanu $\mathbf{S}^{\circ}$ 2017. This is an open-access article distributed under the terms of the Creative Commons Attribution License, which permits unrestricted use, distribution and reproduction in any medium, provided the original author and source are credited. 
microbiological quality of ready-to-eat food in general has limits for hygiene indicator organisms like Enterobacteriaceae and E. coli, and specific foodborne pathogens like Salmonella and Shigella species [7].

Therefore to monitor microbiological quality of raw meat products guidelines and recommendations of international and national level have been developed in addition to legal requirements. According to the guidelines classification of microbiological quality into one of three classes: satisfactory if the test results indicating good microbiological quality; borderline if the test results are on the upper limit of acceptability and which indicate the potential for development of public health problems and of unacceptable risk; and unsatisfactory if the test result for hygiene indicator organisms that require remedial action and for pathogens, which indicate potentially injurious to health and/or unfit for human consumption and require immediate remedial action [7-9].

In spite of the aforementioned prevailing situation, there is limited information documented on the layout and sanitary condition of slaughterhouses and meat stalls; and microbial quality of market meats in meat stalls of the study area, because understanding them was crucial in improvement interventions on public health with improving the sanitation of the slaughterhouses abattoirs and meat stalls; and it is a prerequisite in the market orientation supply of meat at local and national level. Therefore this study was undertaken: to assess human resource capabilities, sanitation of slaughter houses and processing materials, and meat-stall butchers' meat handling practices; and to evaluate hygiene indicator microorganisms and specific foodborne pathogens.

\section{Materials and Methods}

\section{Sampling}

The study was conducted in DebreMarkos, Dejen, Bure and Fenoteselam administrative towns of Mirab-Gojjam and MisraqGojjam Zones. For the survey study totally 54 slaughterhouse butchers: 22 from Debremarkos, 5 from Dejen, 10 from Bure and 17 from Finoteselam were assessed with observation survey using checklist and interviewed using structured questioner. Beside of this, butchers and slaughterhouse status of each town was evaluated using a checklist with thorough observation.

From 21 randomly selected meat-stalls: four from Bure, eight from Debremarkos, four from Dejen and five from Fenote selam meat samples were taken for evaluation of hygienic handling indicator enteric microorganisms. From each meat-stall subsamples were taken from different parts of the available carcass; butchers comminute the subsamples with them knife and thoroughly mixed to form a composite sample. Samples were collected crosssectionally between April and August 2014; and transported kept in cold sterile screw cap bottles with ice contained icebox to DebreMarkos University College of Agriculture and Natural Resource Management Animal Science Laboratory for lab analysis.

\section{Preparation of Test Sample and Serial Dilution}

Blended 25g of comminuted composite meat sample with $225 \mathrm{ml}$ of peptone water (HIMEDIA) solution. Further decimal dilutions were carried out up to fourth dilution at 1:10 ratios with peptone water diluents [9].

\section{Enumeration of Enteric Bacteria}

Enumeration of Enterobacteriaceae, Escherichia coli, and Salmonella and Shigella species had been taken from the highest to the lowest consecutive serial dilutions in duplicate on Violet red bile agar (VRBA) (HIMEDIA) from $4^{\text {th }}$ to 1 st; MacConkey agar (MCA) (HIMEDIA) from $4^{\text {th }}$ to 1 st and Salmonella Shegela agar (SSA) (HIMEDIA) from $2^{\text {nd }}$ and $1^{\text {st }}$ dilutions respectively. The inoculant was inoculated at the center of accordingly labeled pre dried Petri dishes of VRBA, MCA and SSA plates. Inoculum was spread using sterilized hockey glass spreader and incubated at 35 to $37^{\circ} \mathrm{C}$ for $48 \pm 2 \mathrm{hr}$. Then VRBA and MCA plates containing 15 to 150 colonies and all colonies of SSA plates were recorded and average of the colonies counted as number of colony forming units per gram $(\mathrm{cfu} / \mathrm{g})$ for each sample.

\section{Bacterial Isolates}

Confirmed Oxides negative Enterobacteriaceae family from VRBA were undertaken for dextrose, lactose and sucrose fermentation, and hydrogen sulphide production with Triple Sugar-Iron Agar medium (HIMEDIA); for citrate utilization with Simmons Citrate Agar (HIMEDIA); for Methyl Red and VogesProskauer tests with MR-VP Medium (HIMEDIA); and XyloseLysine Deoxycholate Agar(HIMEDIA).

\section{Method of Data Analysis}

The survey data was analyzed with simple descriptive statistics. And count of hygienic handling indicator enteric microorganisms $\log _{10}$ transformed value was analyzed with mixed procedure using Statistical Analysis Software (SAS) 9.2 to determine the difference between fixed effect of places and random effect of meat-stalls. For the fixed effect (administrative town), least square difference was used to separate means when the parameter tests were significantly different at $\mathrm{P}<0.05$. The PROC MIXED estimates the variance components for the meat-stalls and the residual by default used Restricted Maximum Likelihood Estimation (REML). The convergence criteria of colony forming unit bacterial count of Entrobacteriaceae, Escherichia coli, and Salmonella and Shigella species were met at the fourth, second and sixth iteration respectively. In addition standardization of colony counts and isolates were analyzed with a descriptive statistics.

\section{Result and Discussion}

\section{Operational Capacity and Human Resource Capabilities of Slaughterhouses}

The average daily slaughtering capacity of Debremarkos, Dejen, Bure and Finoteselam abattoirs were 25, 10, 7 and 15 cattle respectively. Herewith the overall education profile of abattoir workers shows primarily $40.74 \%$ of them were primary school; secondly $35.19 \%$ were illiterates; and only few of them had been finished secondary and high school education level. Beside of this all of them were professionally not trained and certified. As in all the slaughter house activities in all of the study areas were undertaken through traditional experience; and all abattoir 
workers had no health certificate, except an individual in Finoteselam. However educated, skill full and certified employers has important in the control of foodborne hazards related to all stages of the food chain [10].

Hygienic cleaning of processing materials and clean and overall protective cloth could help to prevent direct and cross contamination of sterile carcass from microorganisms. However all abattoirs had no hot water cleaning system, no slaughtering materials sterilizer and cold room. With this all workers had no overall protective cloth, while only few had used apron, hair cover and gumboots (Table 1). This finding likewise with the research undertaken on assessment of hygiene practices used by small butchers and slaughter slabs in Juba town-South Sudan [11]; and the assessment on hygienic conditions and sanitation practices of slaughterhouses of Jagdalpur city in India [12]. And also in line with this finding both of them found most of the butchers were illiterates and had no health certificate. In addition according to [12] most of the butchers dose not taken professionally related training; and had not used apron and haircover. However personnel must be equipped with the materials and equipment necessary to perform tasks. It has important role in the production of safe foods [10].

\section{Sanitation of Slaughterhouses and Meat-Stalls}

Structures of slaughter house in all places of the study areas were built wooden materials as simple shade for slaughtering process. The entire abattoirs had no clear division of slaughter process in to stunning, slaughtering/bleeding and frozen delivery, which had great opportunity to contaminate the exposed tissues of the carcass with microorganisms. All slaughtering process was taken place simply on the ground and hanging were take place on simply constructed wood. And also there were no preventive mechanisms installed for rodents and insects. The fence around the abattoir will not protect from entrance of stray dogs and other rodents.

Further observation showed that there was no proper disposing system as the result the ruminal contents and other solid wastes, faeces, horns, scraps of tissues and other solid wastes were found near to the abattoir and serve for the reside rodents, cats and vultures. In Dejen and Bure the final processed carcasses were transported by men's and handcarts to the meat stalls but in Debermarkos and Finoteselam old vehicle were used to distribute the carcasses to meat stalls.

In general according to the sanitary condition of slaughterhouse and processing materials measuring criteria all abattoirs were below the average. Relatively Debremarkos (46.15\%) abattoir had better sanitary standard than other abattoirs; and sequentially followed with Fenoteselam (23.08\%), Bure (15.38\%) and Dejen $(7.69 \%)$ (Table 2).

Among 21 meat stalls butchers $9.52 \%$ were not use protective clothes; $52.38 \%$ did not cover their hair; $85.71 \%$ handle money while cutting the meat. Almost all (95.24) of the butchers were neither undertake any form of training in food preparation nor attempt to seek it.

\section{Bacterial Countand Standardization}

Analysis of the variance between places and within places were undertaken (Table 3 and 4). Herewith the hygienic handling indicator microorganisms of Enterobacteriaceae and Escherichia coli colony forming unit count are standardized into satisfactory, borderline and unsatisfactory categories; and the presence of Salmonella and Shigella species in $25 \mathrm{~g}$ meat samples has unsatisfactory quality [7, 8, 13] (Figure 1).

The mean count of Enterobacteriaceae colony forming unit was not significantly $(P \geq 0.05)$ different between places. Where the overall mean $(3.867 \pm 0.3 \mathrm{cfu} / \mathrm{g})$ count is in accordance with a national survey of the microbiological quality of retail raw meats in Australia [14]. On the other hand according to CFS and FSANZ statute [7, 8] $47.62 \%$ of the total sample were categorized in to each of borderline and unsatisfactory quality standard; while only the remain few samples had satisfactory quality. But

Table 1. Abattoir Workers Profile.

\begin{tabular}{|c|c|c|c|c|c|c|c|}
\hline \multicolumn{3}{|c|}{ Criteria's } & $\begin{array}{c}\text { Debrmarkos } \\
n=22\end{array}$ & $\begin{array}{l}\text { Dejen } \\
n=5\end{array}$ & $\begin{array}{c}\text { Bure } \\
\mathrm{n}=10\end{array}$ & $\begin{array}{c}\text { Finoteselam } \\
n=17\end{array}$ & $\begin{array}{l}\text { Total } \\
\mathrm{N}=54\end{array}$ \\
\hline \multicolumn{3}{|c|}{ Illiterate } & $40.91 \%$ & $40.00 \%$ & $30.00 \%$ & $29.41 \%$ & $35.19 \%$ \\
\hline \multirow{3}{*}{$\begin{array}{l}\text { Educational } \\
\text { status }\end{array}$} & \multicolumn{2}{|c|}{ Primary school } & $22.73 \%$ & $60.00 \%$ & $50.00 \%$ & $52.94 \%$ & $40.74 \%$ \\
\hline & \multicolumn{2}{|c|}{ Secondary school } & $27.27 \%$ & - & $10.00 \%$ & $11.77 \%$ & $16.67 \%$ \\
\hline & \multicolumn{2}{|c|}{ High school } & $9.09 \%$ & - & $10.00 \%$ & $5.88 \%$ & $7.41 \%$ \\
\hline \multirow{2}{*}{$\begin{array}{c}\text { Health } \\
\text { certificate }\end{array}$} & \multicolumn{2}{|l|}{ Yes } & - & - & - & $5.88 \%$ & $1.85 \%$ \\
\hline & \multicolumn{2}{|l|}{ No } & $100 \%$ & $100 \%$ & $100 \%$ & $94.12 \%$ & $98.15 \%$ \\
\hline \multirow{8}{*}{$\begin{array}{l}\text { Protective } \\
\text { clothing }\end{array}$} & \multirow{2}{*}{ Overall cloth } & Yes & - & - & - & - & - \\
\hline & & No & $100 \%$ & $100 \%$ & $100 \%$ & $100 \%$ & $100 \%$ \\
\hline & \multirow{2}{*}{ Aprons } & Yes & $13.64 \%$ & $20.00 \%$ & $30.00 \%$ & $17.65 \%$ & $18.52 \%$ \\
\hline & & No & $86.36 \%$ & $80.00 \%$ & $70.00 \%$ & $82.35 \%$ & $81.48 \%$ \\
\hline & \multirow{2}{*}{ Hair cover } & Yes & $31.82 \%$ & $20.00 \%$ & $40.00 \%$ & $29.41 \%$ & $31.48 \%$ \\
\hline & & No & $68.18 \%$ & $80.00 \%$ & $60.00 \%$ & $70.59 \%$ & $68.52 \%$ \\
\hline & \multirow{2}{*}{ Gumboots } & Yes & - & - & $10.00 \%$ & $17.65 \%$ & $7.41 \%$ \\
\hline & & No & $100 \%$ & $100 \%$ & $90.00 \%$ & $82.35 \%$ & $92.59 \%$ \\
\hline
\end{tabular}


Table 2. Sanitary Condition of Slaughterhouse and Processing Materials.

\begin{tabular}{|c|c|c|c|c|c|}
\hline \multicolumn{2}{|l|}{ Measuring criteria's } & Debrmarkos & Dejen & Bure & Finoteselam \\
\hline \multicolumn{2}{|c|}{ Does it have effective effluent disposal area? } & $\mathrm{No}$ & No & No & $\mathrm{No}$ \\
\hline \multicolumn{2}{|c|}{ Is there sufficient separation between the clean and dirty area? } & No & $\mathrm{No}$ & $\mathrm{No}$ & $\mathrm{No}$ \\
\hline \multicolumn{2}{|c|}{ Is there hygiene and sanitary system } & No & No & No & No \\
\hline \multicolumn{2}{|l|}{ Equipment made of stainless steel? } & Yes & $\mathrm{No}$ & $\mathrm{No}$ & $\mathrm{No}$ \\
\hline \multicolumn{2}{|c|}{ Is there sufficient drainage in the abattoir? } & Yes & No & No & No \\
\hline \multicolumn{2}{|c|}{ Is the sewage disposal system environmental friendly? } & No & No & No & No \\
\hline \multicolumn{2}{|l|}{ Does it have a lairage } & Yes & No & No & Yes \\
\hline \multicolumn{2}{|l|}{ Is the lairage well ventilated? } & Yes & Yes & Yes & Yes \\
\hline \multicolumn{2}{|c|}{ Is there an isolation pen for sick animals? } & No & No & No & No \\
\hline \multicolumn{2}{|c|}{ Is hot and cold water supply available in the laboratory? } & No & No & No & No \\
\hline \multicolumn{2}{|l|}{ Is there an incinerator? } & Yes & No & No & No \\
\hline \multicolumn{2}{|c|}{ Is there an emergency slaughter room? } & No & No & No & No \\
\hline \multicolumn{2}{|c|}{$\begin{array}{l}\text { Is there a post-mortem inspection area for animals arriving dead or } \\
\text { die in the lairage? }\end{array}$} & Yes & No & Yes & Yes \\
\hline \multirow{2}{*}{ Percentage of overall standard criteria } & Yes & $46.15 \%$ & $7.69 \%$ & $15.38 \%$ & $23.08 \%$ \\
\hline & No & $53.85 \%$ & $92.31 \%$ & $84.62 \%$ & $76.92 \%$ \\
\hline
\end{tabular}

Figure 1. Standardization of hygienic handling indicator microorganisms.

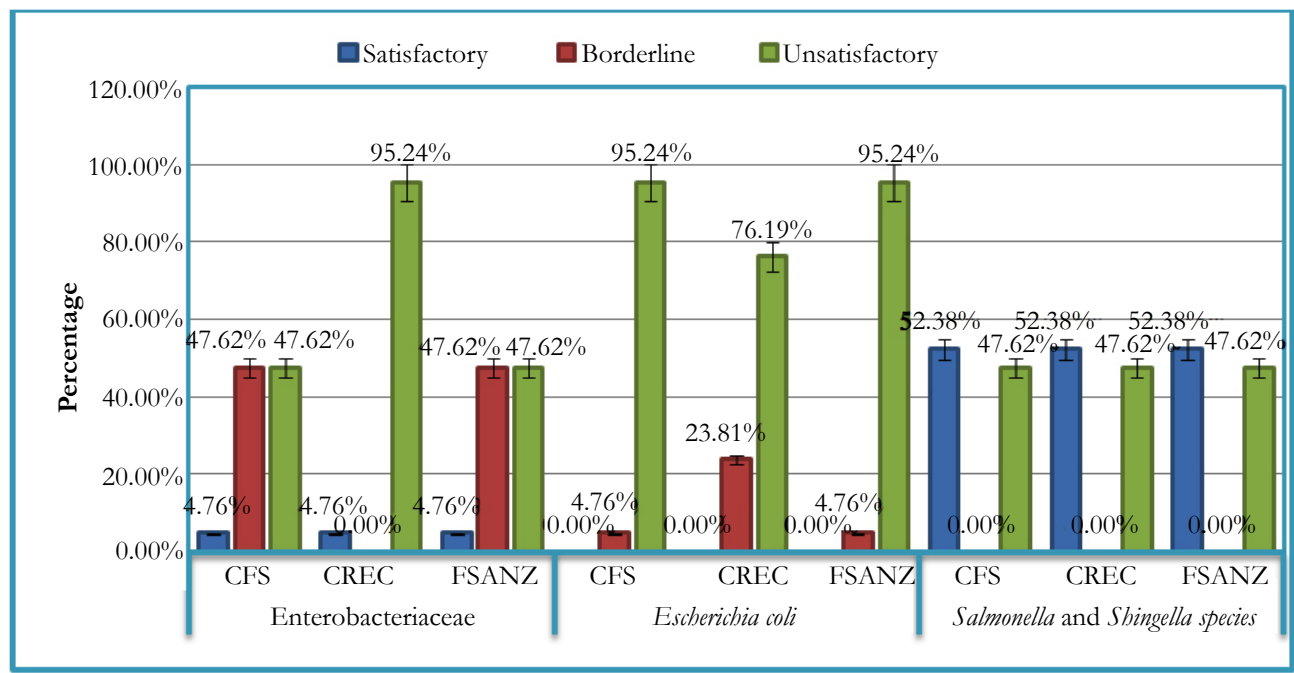

according to CREC statute [13] most (95.24\%) of the samples had unsatisfactory quality. This result is in line with a national survey of the microbiological quality of retail raw meats in Australia [14] where detected in $96.9 \%$ of ground beef samples. The meat could contaminate from slaughtering surfaces and slaughtering materials of abattoirs; meat handlers and transportation; or hygienic handling and processing of meat-stalls.

The mean count of Escherichia coli was significantly ( $\mathrm{P} \geq 0.05$ ) different between places. Its least square mean differences indicate that the highest count $(4.628 \pm 0.317 \mathrm{cfu} / \mathrm{g})$ was found from Dejen, where the least percentage of overall standard criteria of sanitary condition of slaughterhouse and processing materials were found. However it was not significantly $(\mathrm{P} \geq 0.05)$ different from the mean count of Debremarkos, where relatively the highest percentage of overall standard criteria of sanitary condition of slaughterhouse and processing materials were found. In contrast the least count $(2.871 \pm 0.317 \mathrm{cfu} / \mathrm{g})$ was found from Bure; however it was not significantly $(P \geq 0.05)$ different from the mean count of Fenoteselam. The mean bacterial count found from Bure and Fenoteselam is comparable with the microbial load of 2.81 and $2.94 \mathrm{cfu} / \mathrm{cm}^{2}$ found from abattoirs and retail outlet beef samples respectively [15]; but it is unlike with a national survey of the microbiological quality of retail raw meats in Australia [14], where found $1.67 \mathrm{cfu} / \mathrm{g}$. On the other hand, most $(95.24 \%)$ of the meat samples had unsatisfactory quality according to CFS and FSANZ statute $[7,8]$; and the remaining few $(4.76 \%)$ samples were categorized under borderline. But regarding of CREC statute [13] $23.81 \%$ and $76.19 \%$ of the meat samples had borderline and unsatisfactory quality respectively. As in all the count of Escherichia coli indicates there has been contamination of faecal origin from poor hygienic practices. Instead cross contamination from raw meat contact surfaces, meat handlers or there has been inadequate processing.

The mean count of Salmonella and Shigella species was significantly 
Table 3. Least square means difference in $\log$ CFU g ${ }^{-1}$ of Violet Red Bile agar, MacConkey agar and Salmonella Shigella agar plats count of enteric bacteria.

\begin{tabular}{|c|c|c|c|c|c|c|}
\hline \multirow{2}{*}{ Place } & \multicolumn{2}{|c|}{ Enterobacteriaceae } & \multicolumn{2}{|c|}{ Escherichia coli } & \multicolumn{2}{|c|}{ Salmonella and Shigella species } \\
\hline & \multicolumn{2}{|c|}{ Estimate \pm SE } & \multicolumn{2}{|c|}{ Estimate $\pm \mathrm{SE}$} & \multicolumn{2}{|c|}{ Estimate $\pm \mathrm{SE}$} \\
\hline Bure & \multicolumn{2}{|c|}{$3.667 \pm 0.335$} & \multicolumn{2}{|c|}{$2.871 \pm 0.317^{c}$} & \multicolumn{2}{|c|}{$3.227 \pm 0.369^{\mathrm{a}}$} \\
\hline DebreMarkose & \multicolumn{2}{|c|}{$3.82 \pm 0.253$} & \multicolumn{2}{|c|}{$4.080 \pm 0.231^{\mathrm{ab}}$} & \\
\hline Dejen & \multicolumn{2}{|c|}{$4.468 \pm 0.335$} & \multicolumn{2}{|c|}{$4.628 \pm 0.317^{\mathrm{a}}$} & \multicolumn{2}{|c|}{$1.743 \pm 0.495^{\mathrm{b}}$} \\
\hline Fenoteselam & \multicolumn{2}{|c|}{$3.867 \pm 0.300$} & \multicolumn{2}{|c|}{$3.189 \pm 0.287^{\mathrm{bc}}$} & \multicolumn{2}{|c|}{$3.113 \pm 0.356^{a}$} \\
\hline Effect & F Value & $\operatorname{Pr}>F$ & F Value & $\operatorname{Pr}>F$ & F Value & $\operatorname{Pr}>\mathrm{F}$ \\
\hline Intercept & 661.67 & $<.0001$ & 368.44 & $<.0001$ & 56.52 & 0.0017 \\
\hline Place & 1.14 & 0.3834 & 9.73 & 0.0026 & 7.1 & 0.0728 \\
\hline
\end{tabular}

*Means in a column with the same letter are not significant different $(P \geq 0.05)$.

Table 4. The covariance parameter estimate of random effects.

\begin{tabular}{|c|c|c|c|c|}
\hline Parameters & & Estimate \pm SE & Z Value & Pr $>$ Z \\
\hline \multirow{2}{*}{ Enterobacteriaceae } & Meat-stall & 0 &. &. \\
\cline { 2 - 5 } & Residual & $0.449 \pm 0.159$ & 2.83 & 0.0023 \\
\hline \multirow{2}{*}{ Escherichia coli } & Meat-stall & $0.138 \pm 0.151$ & 0.91 & 0.1812 \\
\cline { 2 - 5 } & Residual & $0.29 \pm 0.125$ & 2.31 & 0.0103 \\
\hline \multirow{2}{*}{ Salmonella and Shigella species } & Meat-stall & $0.534 \pm 0.449$ & 1.19 & 0.1171 \\
\cline { 2 - 5 } & Residual & $0.1 \pm 0.086$ & 1.15 & 0.1241 \\
\hline
\end{tabular}

$*=$ cannot be computed.

$(\mathrm{P} \geq 0.05)$ different between places. The least square mean difference of Salmonella and Shigella species shows that the highest $(3.227 \pm 0.369 \mathrm{cfu} / \mathrm{g})$ colony forming unit count were found from Bure, where the second least percentage of overall standard criteria of sanitary condition of slaughterhouse and processing materials were. But it was not significantly $(P \geq 0.05)$ different from Fenoteselam. This inadequate processing of raw meat products; cross contamination or contaminated materials; and poor time and temperature control during transportation might be a contributed factor for the higher count of colony forming units. Salmonella and Shigella species were no detected from Debremarkos meat samples even the overall standard criteria of sanitary condition of slaughterhouse and processing materials were below the average. Along with this Salmonella and Shigella species were detected from $47.62 \%$ of the total meat sample, so according to CFS, FSANZ AND CREC statute $[7,8,13]$ almost half of the meat samples had unsatisfactory quality. This finding is comparable with different previse findings undertaken in abattoir, retaile raw meat and/ or meat productes [5, 14-17]; were detected Salmonella at different level from abattoir, meat and meat processing materials.

The variance estimate of meat-stalls and residual are presented in Table 4. It indicates that the variance component of the mean count of Enterobacteriaceae was significantly $(P \geq 0.05)$ equals to zero. It means no difference was found among meat-stalls between places. However, the variance components of meat-stalls Escherichia coli, and Salmonella and Shigella species count were not significantly $(P \geq 0.05)$ equals to zero. These estimates suggested that there were difference in their mean Escherichia coli, and Salmonella and Shigella species count among meat-stalls between places (Table 4).
Percentage of Enterobacteriaceae count: according to CFS and FSANZ statute, if the count $<10^{2} \mathrm{cfu} / \mathrm{g}=$ Satisfactory, $10^{2}$ to $\leq 10^{4} \mathrm{cfu} / \mathrm{g}=$ Borderline and $>10^{4} \mathrm{cfu} / \mathrm{g}=$ Unsatisfactory; while according to CREC statute, if the count $<3.5 \mathrm{log} \mathrm{cfu} / \mathrm{cm}^{2}=$ Satisfactory, 3.5 to $5 \log \mathrm{cfu} / \mathrm{cm}^{2}=$ Borderline and $>5 \log \mathrm{cfu} / \mathrm{cm}^{2}$ $=$ Unsatisfactory. Percentage of Escherichia coli count: according to CFS statute, if the count $<20 \mathrm{cfu} / \mathrm{g}=$ Satisfactory, 20 to $<10^{2}=$ Borderline and $>10^{2}=$ Unsatisfactory; CREC statute, if the count $<50 \mathrm{cfu} / \mathrm{g}=$ Satisfactory, 50 to $500 \mathrm{cfu} / \mathrm{g}=$ Borderline and $>$ $500 \mathrm{cfu} / \mathrm{g}=$ Unsatisfactory; and FSANZ statute, if the count $>10^{2} \mathrm{cfu} / \mathrm{g}=$ Unsatisfactory. Percentage of Salmonella and Shigella species count: according to CFS, FSANZ and CREC statute, no detection in $25 \mathrm{~g}$ sample has Satisfactory quality.

\section{Isolates}

As indicated in Table 5, from the total meat sample Escherichia coli (0.762) and Proteus vulgaris (0.381) were found in a higher ratio as compared with Salmonella Species (0.19), Shigella flexneri (0.143) and Klebsiella pneumonia (0.095). The occurrence of enteric bacterial species isolate per sample size of the study area, Bure and Finoteselam was equally leading with the ratio of 2 ; and followed by DebreMarkos (1.375) and Dajen (1). In general totally 33 enteric bacterial species were isolated. From these isolates the highest ratio were detected from Debremarkos, Finoteselam, Bure and Dejen sequentially. The higher rate of contamination of meat with these organisms is an indication of deplorable state of poor hygienic and sanitary practices employed right from the slaughtering, transportation to butcher shops and processing. 
Table 5. Isolates of enteric bacteria species and ratio of isolates occurred from meat samples.

\begin{tabular}{|c|c|c|c|c|c|}
\hline Isolates & Bure $(\mathrm{n}=4)^{\mathrm{c}}$ & DebreMarkos $(\mathrm{n}=8)^{\mathrm{c}}$ & Dajen $(\mathrm{n}=4)^{\mathrm{c}}$ & ${\text { Finoteselam }(\mathrm{n}=5)^{\mathrm{c}}}^{\text {Ratio of I/N }}$ \\
\hline Escherichia coli & 3 & 8 & 1 & 4 & 0.762 \\
\hline Salmonella Spp. & 1 & & 1 & 2 & 0.19 \\
\hline Shigella flexneri & & & & 3 & 0.143 \\
\hline Proteus vulgaris & 3 & 2 & 2 & 1 & 0.381 \\
\hline Klebsiellapneumoniae & 1 & 1 & & & 0.095 \\
\hline Ratio of a/ $\mathrm{n}$ & 2 & 1.375 & 1 & 2 & \\
\hline Ratio of a/total isolates & 0.250 & 0.344 & 0.125 & 0.313 & \\
\hline Total isolates & \multicolumn{7}{|l}{33} & \\
\hline
\end{tabular}

$n$, sample size per place; $c$, number of isolates occurred per $n$; $I$, is total isolates per $N$; which is total sample size $(N=21)$.

However similarly in Nairobi Kenya Escherichia coli was detected from $78 \%$ raw chicken meat [17]. But unlikely in Australia it found only from $17.8 \%$ retail raw meat [14]; and also found from $45 \%$ abattoirs and retail outlets [15]. Herewith $12 \%$ of Proteus species are detected from ready to eat foods vended in streets of Amravati City of India [18]. Salmonella species are disseminated in the natural environment (water, soil, sometimes plants used as food) and through human or animal excretion [19]. Therefore, the presence of such organisms might be derived from water, soil and /or faeces. The presence of Shigella spp. would be indicates the contamination of meat with infected food handlers, sewage, water used for cleaning, flies breed in infected faeces and/or soil of infected area. Shigellosis is an infectious disease caused by various species of Shigella [19].

\section{Conclusions and Recommendations}

In general the unhygienic slaughtering practice with high level of Enterobacteriaceae, Escherichia coli, and Salmonella and Shigella species counts; and isolated pathogenic bacteria in the meat represent poor hygienic handling practices from the beginning to reach meat stalls and also even within meat stalls of all the study areas. In spite of unacceptable microbial quality in general, this could result in public health risk to the consumers.

Therefore, based on the above conclusions the following points are recommended:

> Training should be given to all Abattoir workers, butchers, meat stall workers and drivers on hygienic practice.

$>$ There should be improved hygiene practices at all levels in the meat slaughtering and marketing in the meat stalls.

> Governmental and non-governmental organizations should strengthen awareness campaigns on improved hygiene practices so as to reduce the public health risks and the rate of microbial infections with raw meat consumption.

\section{References}

[1]. Heinz G, Hautzinger P. Meat processing technology for small- to mediumscale producers. Food and Agriculture Organization of the United Nations (FAO); 2007.

[2]. FSA (Food Standards Agency). Meat Industry Guide; 2015.
[3]. Pal M. Raw meat poses public health risks. The Ethiopian Herard. 2012 May 15. 1-78.

[4]. Sofos JN, Kochevar SL, Bellinger GR, Buege DR, Hancock DD, Ingham SC, et al. Sources and extent of microbiological contamination of beef carcasses in seven United States slaughtering plants. J Food Prot. 1999 Feb;62(2):140-145. PubMed PMID: 10030632.

[5]. Bhandare SG, Paturkar AM, Waskar VS, Zende RJ. Bacteriological screening of environmental sources of contamination in an abattoir and the meat shops in Mumbai, India. In: 3rd Indian Meat Science Association Conference, Bangalore, India, July 2008. Asian Journal of Food and Agro-Industry. 2009;2(3): 280-290

[6]. WHO. WHO estimates of the global burden of foodborne diseases: food borne disease burden epidemiology reference group 2007-2015.

[7]. CFS (Centre for Food Safety). Microbiological Guidelines for Food: For ready-to-eat food in general and specific food items. 2014 Aug.

[8]. FSANZ (Food Standards Australia New Zealand). Compendium of Microbiological Criteria for Food. 2016.

[9]. EAS. Microbiology of food and animal feeding stuffs. Preparation of test samples, initial suspension and decimal dilutions for microbiological examination - Part 1-2: General rules for the preparation of the initial suspension and decimal dilutions.

[10]. Hazard Analysis and Critical Control Point Principles and application guidelines. National Advisory Committee on Microbiological Criteria for foods. 1997 Aug 14

[11]. Andrea P, Aburi S. Assessment of Hygiene practices used by Small Butchers and Slaughter Slabs in beef value chain in Juba town-South Sudan. A Research Project to be done and submitted to Van Hall Larenstein University of Applied Science In Partial Fulfillment of the Requirem. Van Hall Larenstein University of Applied Science. 2012 Sep.

[12]. Tuneer K, Madhavi T. A comparative study of Hygienic status of Butchers and Identifybacteria among the Slaughters of Meat, Chicken and Fish markets of Jagdalpur city . Intl Res J Biol Sci. 2015 Jan; 4(1):16-24.

[13]. Commission Regulation (EC) No 2073/2005 of 15th November 2005 on microbiological criteria for foodstuffs. 32 Official Journal of the European Union. Commission Regulation of European Union.

[14]. Phillips D, Jordan D, Morris S, Jenson I, Sumner J. A national survey of the microbiological quality of retail raw meats in Australia. J Food Prot. 2008 Jun;71(6): 1232-1236. PubMed PMID: 18592751.

[15]. Ahmad MU, Sarwar A, Najeeb MI, Nawaz M, Anjum AA, Ali MA, et al. Assessment of Microbial Load of Raw Meat At Abattoirs and Retail Outlets. J Anim Plant Sci. 2013 Jan;23(3):745-748.

[16]. Melngaile A, Ciekure E, Valcina O, Safety F, Health A, Bior E. Microbiological Quality of Meat Preparations and Meat Products. Jan 2014;61-65.

[17]. Odwar JA, Kikuvi G, Kariuki JN, Kariuki S. A Cross-sectional Study on the Microbiological Quality and Safety of Raw Chicken Meats Sold In Nairobi, Kenya. BMC Res Notes. 7(627):2. PubMed PMID: 25204564

[18]. Tambekar DH, Jaiswal VJ, Dhanorkar DV, Gulhane PB, Dudhane MN. Identification of microbiological hazards and safety of ready-to-eat food vended in streets of Amravati City, India. J Appl Biosci. 2008 Jan;7:195201.

[19]. Todar K. Todar's Online Textbook of Bacteriology. 2008. 